Bangladesh J. Plant Taxon. 21(2): 159-165, 2014 (December)

(C) 2014 Bangladesh Association of Plant Taxonomists

\title{
POLLEN MORPHOLOGY OF VERBASCUM L. (SCROPHULARIACEAE) IN NORTHERN AND CENTRAL IRAQ
}

\author{
Muazaz Al-Hadeethy, Athiya Al-Mashhadani, Talib Al-KhesRaji ${ }^{1}$, Sahapat \\ Barusrux $^{2}$, Hazim Al-Jewari, Piyada TheErakulpisut ${ }^{3}$ and Pimwadee \\ PORNPONGRUNGRUENG ${ }^{3,4}$ \\ Department of Biology, College of Education-Ibn Al-Haitham, University of Baghdad, \\ Baghdad, Iraq \\ Keywords: Pollen morphology; SEM; Taxonomy; Verbascum; Iraq.
}

\begin{abstract}
The present study highlights the taxonomic values of the pollen features of 20 species of Verbascum L. in Iraq. The pollen grains were acetolysed and observed under Light and Electron microscopes. Our results showed that the pollen grains of these species are usually radially symmetrical, isopolar, tricolporate and display reticulate sculpturing. The variations were found in shape, size, and exine thickness. Most of the species are subprolate, prolate spheroidal, and prolate, whereas oblate spheroidal pollens were found only in $V$. thapsus. The pollen size among the species studied ranges from 16.2-32.5 $\mu \mathrm{m}$. The majority of species are medium sized except $V$. agrimoniifolium and $V$. oreophilum that are small sized, and four species i.e. $V$. palmyrense, $V$. sinuatum, $V$. songaricum, and $V$. thapsus having both small and medium sized pollen grains. Moreover, the result showed that the exine thickness ranges from $0.87-4.75 \mu \mathrm{m}$, but this value can overlap between some species. Therefore, only the shape of pollen grains could be used to classify these species into groups.
\end{abstract}

\section{Introduction}

The genus Verbascum L. (Scrophulariaceae) is mostly herbaceous with few shrubs and climbers, comprises about 350 species, and it is distributed all over the world (Zohary, 1974). Verbascum is widely spread in the Arabian Peninsula, especially in Saudi Arabia, Oman and Yemen (Huber-Morath, 1978; Ghadanfar, 1992; Wood, 1997). In Iraq, Verbascum is represented by 26 species (AL-Rawi, 1964; AL-Bermani, 1981).

The taxonomy of Verbascum species in Iraq is still uncertain, especially that as related to the geographical distribution of the species, the morphological variation and the condition of herbarium samples (AL-Bermani, 1981). Therefore, study of different characteristics would help in resolving the relationships and delimitation of these species. Pollen morphology is proved to be a useful character for improving the accuracy in the identification and classification of several plant groups (Erdtman, 1952; Rajbhandary et al., 2012; Özler et al., 2013; Sawar and Takahashi, 2013). Despite pollen morphology of Verbascum species was studied by several authors (Erdtman, 1952; Filippini et al., 1990; Perveen, 1993; Lobin and Pormbski, 1994; Bukhari and Alfarhan, 2006; Kheiri et al., 2006; Pehlivan et al., 2008), the pollens of Verbascum found in Iraq has never been investigated. Therefore, this study was designed to investigate constant and diagnostic pollen morphological characteristics to be used as a tool for improving the accuracy in the identification and classification of Verbascum, and further authentication of the taxa.

${ }^{1}$ Department of Biology, College of Education, University of Tikrit, Tikrit, Iraq

${ }^{2}$ Centre for Research and Development of Medical Diagnostic Laboratories (CMDL), Faculty of Associated Medical Sciences, Khon Kaen University, Khon Kaen, Thailand

${ }^{3}$ Applied Taxonomic Research Center, Department of Biology, Faculty of Science, Khon Kaen University, Khon Kaen, Thailand

${ }^{4}$ Corresponding author: Email: ppimwa@kku.ac.th 


\section{Materials and Methods}

Pollen sample of 20 species of Verbascum L. grown in the north and central areas of Iraq, were collected between April 2012 and May 2013 (Table 1). The voucher specimens have been deposited in the herbarium of College of Education, Ibn Al-Haitham, University of Baghdad, Iraq. The pollen was prepared using the acetolysis method as described by Erdtman (1960). The measurements and observations were carried out using both Light microscope (LM) and Scanning Electron microscope (SEM). For LM analysis, the acetolysed pollens were placed in a small vial, and 5-7 drops of silicone oil were added, and then the samples were mounted on a glass slide sealed with paraffin and observed under light microscope. The measurements of polar axis (P), equatorial diameter $(\mathrm{E})$ and exine thickness of pollen were done using 10 reading samples for each specimen. For SEM investigation, the acetolysed pollen was suspended in $100 \%$ ethanol. Then the suspension was dried on an aluminum stub, coated with gold and observed using LEO 1450VP Electron Microscopy. The terminology and pollen size classes follow Walker and Doyle (1975) and Punt et al. (1994).

Table 1. List of Verbascum L. species in Northern and Central of Iraq employed in the present study.

\begin{tabular}{|c|c|c|c|}
\hline Species & Locations & $\begin{array}{l}\text { Date of } \\
\text { collections }\end{array}$ & Collection numbers \\
\hline $\begin{array}{l}\text { 1. Verbascum agrimoniifolium } \\
\text { (C. Koch) Hub. - Mor. }\end{array}$ & Sulaymaniyah Province & 14 Jun 2012 & M. AL-Hadeethy 166A \\
\hline $\begin{array}{l}\text { 2. V. alceoides Boiss. \& Hausskn. ex } \\
\text { Boiss. }\end{array}$ & Sulaymaniyah Province & 6 May 2012 & M. AL-Hadeethy 235 \\
\hline 3. V. alepense Benth. & Nineveh Province & 11 May 2013 & M. AL-Hadeethy 245 \\
\hline 4. V. andrusii Post & Nineveh Province & 27 Jun 2012 & M. AL-Hadeethy 129 \\
\hline $\begin{array}{l}\text { 5. V. assurense (Bornm. \& Hand. - } \\
\text { Mazz.) Hub. - Mor. }\end{array}$ & Diyala Province & 4 Apr 2012 & M. AL-Hadeethy 172 \\
\hline $\begin{array}{l}\text { 6. V. calvum Boiss. \& Kotschy ex } \\
\text { Boiss. }\end{array}$ & Sulaymaniyah Province & 14 Jun 2012 & M. AL-Hadeethy 250 \\
\hline 7. V. carduchorum Bornm. & Sulaymaniyah Province & 21 Apr 2012 & M. AL-Hadeethy 168 \\
\hline 8. V. cheiranthifolium Boiss. & Sulaymaniyah Province & 4 May 2012 & M. AL-Hadeethy 225 \\
\hline 9. V. damascenum Boiss. & Anbar Province & 5 Apr 2013 & M. AL-Hadeethy 152 \\
\hline 10. V. geminiflorum Hochst. & Sulaymaniyah Province & 6 May 2012 & M. AL-Hadeethy 230 \\
\hline $\begin{array}{l}\text { 11. V. laetum Boiss. \& Hausskn. ex } \\
\text { Boiss. }\end{array}$ & Sulaymaniyah Province & 20 Apr 2012 & M. AL-Hadeethy 144 \\
\hline 12. V. macrocarpum Boiss. & Sulaymaniyah Province & 4 May 2012 & M. AL-Hadeethy 200A \\
\hline 13. V. oreophilum C. Koch & Sulaymaniyah Province & 5 May 2012 & M. AL-Hadeethy 223 \\
\hline 14. V. palmyrense Post & Nineveh Province & 27 Jun 2012 & M. AL-Hadeethy 220 \\
\hline 15. V. pseudodigitalis Nábělek & Sulaymaniyah Province & 20 Apr 2012 & M. AL-Hadeethy 123 \\
\hline 16. V. sinaiticum Benth. & Nineveh Province & 27 Jun 2012 & M. AL-Hadeethy 112 \\
\hline 17. V. sinuatum L. & Kirkuk Province & 7 Aug 2012 & M. AL-Hadeethy 166B \\
\hline 18. V. songaricum Schrenk & Sulaymaniyah Province & 4 May 2012 & M. AL-Hadeethy 200B \\
\hline 19. V. speciosum Schrad. & Sulaymaniyah Province & 21 Apr 2012 & M. AL-Hadeethy 182 \\
\hline 20. V. thapsus L. & Sulaymaniyah Province & 20 Apr 2012 & M. AL-Hadeethy 145 \\
\hline
\end{tabular}




\section{Results and Discussion}

The results of the pollen morphology of Verbascum are summarized in Table 2. It was found that the pollen morphology of the species studied is uniform. The general characteristic is monad, radially symmetrical, isopolar, tricolporate and reticulate in exine sculpturing (Figs $1 \& 2$ ).
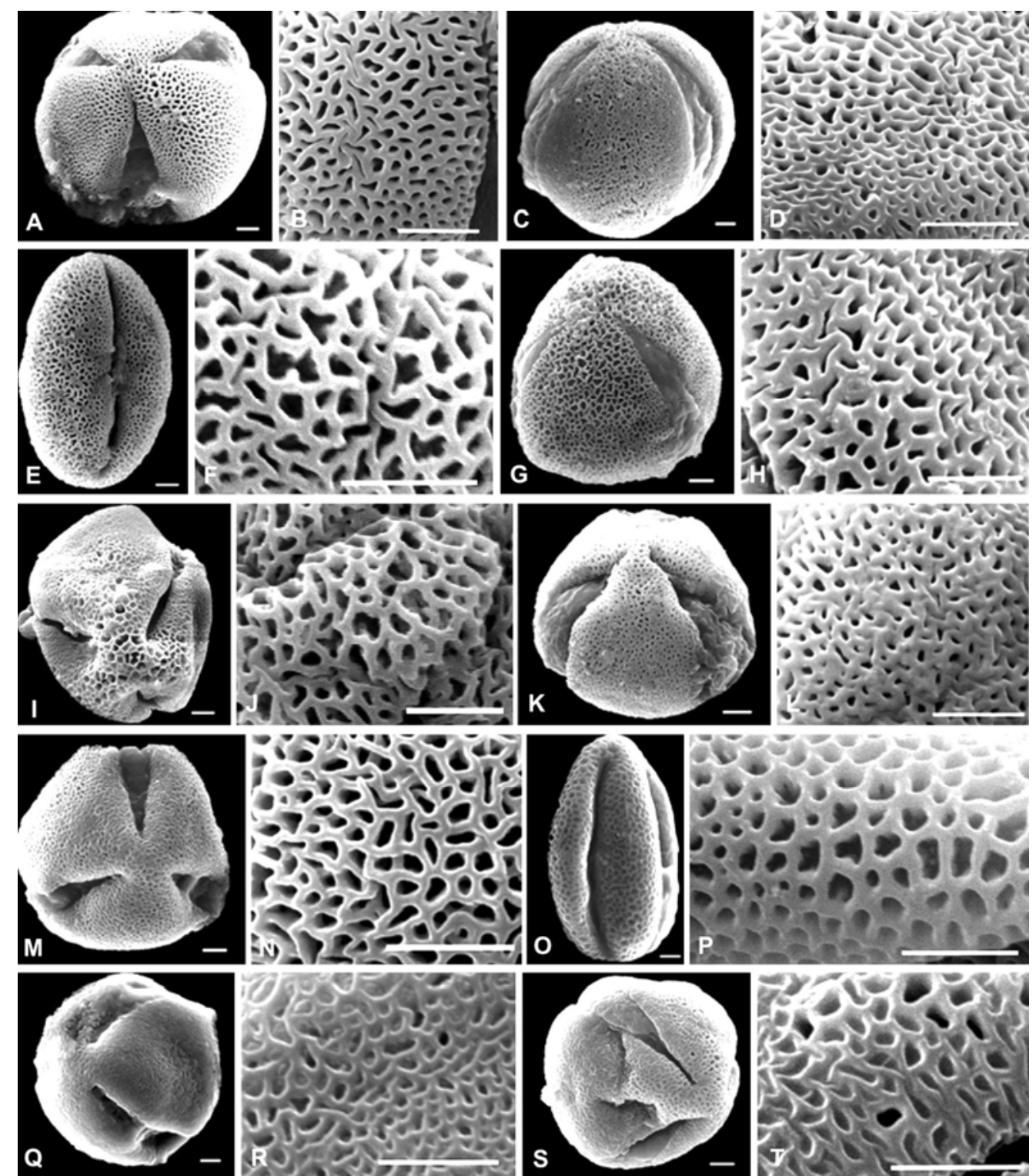

Fig. 1. SEM micrographs of the pollen grains of Verbascum. A, B. V. agrimoniifolium; C, D. V. alceoides; E, F. V. alepense; G, H. V. andrusii; I, J. V. assurense; K, L. V. calvum; M, N. V. carduchorum; O, P. V. cheiranthifolium; Q, R. V. damascenum; S, T. V. geminiflorum; A, G, I, K, M and Q. polar view; B, D, F, H, J, L, N, P, R and T. exine sculpturing; C, E, O, S. equatorial view (Scale bar $=2 \mu \mathrm{m}$ ). 
Table 2. Pollen morphological characteristics of Verbascum in Northern and Central Iraq.

\begin{tabular}{|c|c|c|c|c|c|c|c|}
\hline Species & $\begin{array}{l}\text { Polar axis } \\
(\mu \mathrm{m})\end{array}$ & $\begin{array}{l}\text { Equatorial axis } \\
(\mu \mathrm{m})\end{array}$ & $\begin{array}{l}\mathrm{P} / \mathrm{E} \\
\text { Ratio }\end{array}$ & Shape & Size & $\begin{array}{l}\text { Exine } \\
\text { thickness }(\mu \mathrm{m})\end{array}$ & $\begin{array}{l}\text { Exine } \\
\text { sculpturing }\end{array}$ \\
\hline 1. V. agrimoniifolium & $\begin{array}{l}16.5-20.5 \\
(17.54 \pm 1.39)\end{array}$ & $\begin{array}{l}15.5-21.0 \\
(17.39 \pm 1.65)\end{array}$ & 1.01 & $\begin{array}{l}\text { Prolate } \\
\text { spheroidal }\end{array}$ & small & $\begin{array}{l}0.87-1.05 \\
(0.93 \pm 0.10)\end{array}$ & Reticulate \\
\hline 2. V. alceoides & $\begin{array}{l}27.5-32.5 \\
(28.05 \pm 1.78)\end{array}$ & $\begin{array}{l}22.5-25.0 \\
(24.13 \pm 1.13)\end{array}$ & 1.16 & Subprolate & medium & $\begin{array}{l}2.75-3.00 \\
(2.65 \pm 0.41)\end{array}$ & Reticulate \\
\hline 3. V. alepense & $\begin{array}{l}25.0-27.5 \\
(26.38 \pm 1.04)\end{array}$ & $\begin{array}{l}21.3-22.5 \\
(21.88 \pm 0.63)\end{array}$ & 1.21 & Subprolate & medium & $\begin{array}{l}3.00-3.72 \\
(3.22 \pm 0.39)\end{array}$ & Reticulate \\
\hline 4. V. andrusii & $\begin{array}{l}26.25-27.5 \\
(26.88 \pm 0.63)\end{array}$ & $\begin{array}{l}18.8-20.0 \\
(19.25 \pm 0.61)\end{array}$ & 1.40 & Prolate & medium & $\begin{array}{l}1.25-2.50 \\
(2.15 \pm 0.48)\end{array}$ & Reticulate \\
\hline 5. V. assurense & $\begin{array}{l}27.5-32.5 \\
(30.88 \pm 1.68)\end{array}$ & $\begin{array}{l}25.0-27.5 \\
(26.50 \pm 1.22)\end{array}$ & 1.17 & Subprolate & medium & $\begin{array}{l}3.75-4.25 \\
(4.18 \pm 0.44)\end{array}$ & Reticulate \\
\hline 6. V. calvum & $\begin{array}{l}27.5-30.0 \\
(29.00 \pm 1.09)\end{array}$ & $\begin{array}{l}22.5-25.0 \\
(24.13 \pm 1.13)\end{array}$ & 1.20 & Subprolate & medium & $\begin{array}{l}1.25-2.50 \\
(2.08 \pm 0.51)\end{array}$ & Reticulate \\
\hline 7. V. carduchorum & $\begin{array}{l}25.0-28.8 \\
(27.13 \pm 1.38)\end{array}$ & $\begin{array}{l}22.5-25.0 \\
(24.00 \pm 1.22)\end{array}$ & 1.13 & $\begin{array}{l}\text { Prolate } \\
\text { spheroidal }\end{array}$ & medium & $\begin{array}{l}3.25-4.00 \\
(3.13 \pm 0.76)\end{array}$ & Reticulate \\
\hline 8. V. cheiranthifolium & $\begin{array}{l}26.3-27.5 \\
(26.88 \pm 0.63)\end{array}$ & $\begin{array}{l}20.0-22.5 \\
(21.38 \pm 1.18)\end{array}$ & 1.26 & Subprolate & medium & $\begin{array}{l}1.25-2.50 \\
(2.00 \pm 0.58)\end{array}$ & Reticulate \\
\hline 9. V. damascenum & $\begin{array}{l}27.5-30.0 \\
(29.25 \pm 1.00)\end{array}$ & $\begin{array}{l}20.0-22.5 \\
(21.6 \pm 0.98)\end{array}$ & 1.35 & Prolate & medium & $\begin{array}{l}3.75-4.75 \\
(4.00 \pm 0.58)\end{array}$ & Reticulate \\
\hline 10. V. geminiflorum & $\begin{array}{l}26.25-27.5 \\
(26.50 \pm 0.93)\end{array}$ & $\begin{array}{l}20.0-22.5 \\
(21.13 \pm 1.04)\end{array}$ & 1.25 & Subprolate & medium & $\begin{array}{l}3.00-4.75 \\
(3.58 \pm 1.28)\end{array}$ & Reticulate \\
\hline 11. V. laetum & $\begin{array}{l}30.0-32.5 \\
(31.23 \pm 0.97)\end{array}$ & $\begin{array}{l}23.8-25.0 \\
(24.50 \pm 0.61)\end{array}$ & 1.27 & Subprolate & medium & $\begin{array}{l}2.50-3.75 \\
(3.05 \pm 0.46)\end{array}$ & Reticulate \\
\hline 12. V. macrocarpum & $\begin{array}{l}27.5-28.8 \\
(28.13 \pm 0.63)\end{array}$ & $\begin{array}{l}20.0-22.5 \\
(21.75 \pm 1.00)\end{array}$ & 1.29 & Subprolate & medium & $\begin{array}{l}2.50-3.75 \\
(3.23 \pm 0.52)\end{array}$ & Reticulate \\
\hline 13. V. oreophilum & $\begin{array}{l}19.1-22.5 \\
(20.71 \pm 0.61)\end{array}$ & $\begin{array}{l}18.8-20.0 \\
(19.25 \pm 0.61)\end{array}$ & 1.08 & $\begin{array}{l}\text { Prolate } \\
\text { spheroidal }\end{array}$ & small & $\begin{array}{l}1.75-2.50 \\
(1.90 \pm 0.53)\end{array}$ & Reticulate \\
\hline 14. V. palmyrense & $\begin{array}{l}22.5-25.0 \\
(24.00 \pm 1.09)\end{array}$ & $\begin{array}{l}20.0-22.5 \\
(21.25 \pm 1.12)\end{array}$ & 1.13 & $\begin{array}{l}\text { Prolate } \\
\text { spheroidal }\end{array}$ & $\begin{array}{l}\text { small- } \\
\text { medium }\end{array}$ & $\begin{array}{l}1.25-2.50 \\
(2.05 \pm 0.53)\end{array}$ & Reticulate \\
\hline 15. V. pseudodigitalis & $\begin{array}{l}27.5-30.0 \\
(28.75 \pm 0.97)\end{array}$ & $\begin{array}{l}20.0-21.3 \\
(20.88 \pm 0.57)\end{array}$ & 1.38 & Prolate & medium & $\begin{array}{l}2.25-2.50 \\
(2.53 \pm 0.21)\end{array}$ & Reticulate \\
\hline 16. V. sinaiticum & $\begin{array}{l}27.5-30.0 \\
(29.13 \pm 0.98)\end{array}$ & $\begin{array}{l}20.0-21.3 \\
(20.88 \pm 0.57)\end{array}$ & 1.40 & Prolate & medium & $\begin{array}{l}1.50-2.50 \\
(2.00 \pm 0.49)\end{array}$ & Reticulate \\
\hline 17. V. sinuatum & $\begin{array}{l}19.6-25.2 \\
(23.86 \pm 1.09)\end{array}$ & $\begin{array}{l}20.6-23.2 \\
(23.55 \pm 0.61)\end{array}$ & 1.01 & $\begin{array}{l}\text { Prolate } \\
\text { spheroidal }\end{array}$ & $\begin{array}{l}\text { small - } \\
\text { medium }\end{array}$ & $\begin{array}{l}2.00-2.50 \\
(2.30 \pm 0.22)\end{array}$ & Reticulate \\
\hline 18. V. songaricum & $\begin{array}{l}23.8-26.3 \\
(25.38 \pm 0.98)\end{array}$ & $\begin{array}{l}20.0-21.3 \\
(20.38 \pm 0.57)\end{array}$ & 1.25 & Subprolate & $\begin{array}{l}\text { small - } \\
\text { medium }\end{array}$ & $\begin{array}{l}1.25-3.00 \\
(2.13 \pm 0.75)\end{array}$ & Reticulate \\
\hline 19. V. speciosum & $\begin{array}{l}25.0-27.5 \\
(26.50 \pm 1.09)\end{array}$ & $\begin{array}{l}20.0-22.5 \\
(21.25 \pm 1.25)\end{array}$ & 1.25 & Subprolate & medium & $\begin{array}{l}3.50-4.00 \\
(3.70 \pm 0.29)\end{array}$ & Reticulate \\
\hline 20. V. thapsus & $\begin{array}{l}22.5-25.0 \\
(23.75 \pm 0.77)\end{array}$ & $\begin{array}{l}24.0-27.0 \\
(25.00 \pm 0.50)\end{array}$ & 0.95 & $\begin{array}{l}\text { Oblate- } \\
\text { spheroidal }\end{array}$ & $\begin{array}{l}\text { small - } \\
\text { medium }\end{array}$ & $\begin{array}{l}1.24-2.16 \\
(1.91 \pm 0.35)\end{array}$ & Reticulate \\
\hline
\end{tabular}

In Verbascum, pollen grains vary in shape, size and exine thickness. The shape can be prolate spheroidal, subprolate, prolate and oblate-spheroidal. The pollens are small to medium-sized. Most of the species have medium-sized pollens $(25.0-32.5 \mu \mathrm{m})$ except in $V$. agrimoniifolium and $V$. oreophilum, where small-sized pollens $(16.5-24.0 \mu \mathrm{m})$ are observed. Verbascum palmyrense, $V$. sinuatum, $V$. songaricum, and $V$. thapsus have both small and medium sized pollen grains. The polar axis (P) ranged from 16.5-32.5 $\mu \mathrm{m}$. The largest polar axis was recorded in $V$. alceoides, $V$. assurense and $V$. laetum with $32.5 \mu \mathrm{m}$ long and the smallest was found in $V$. agrimoniifolium with 
$16.5 \mu \mathrm{m}$ long. The equatorial diameter (E) ranged from 15.5-27.5 $\mu \mathrm{m}$ and the largest one was present in $V$. assurense with $27.5 \mu \mathrm{m}$, while the smallest was found in $V$. agrimoniifolium. In addition, the exine thickness of the pollen of species studied ranged from 0.87 to $4.75 \mu \mathrm{m}$.
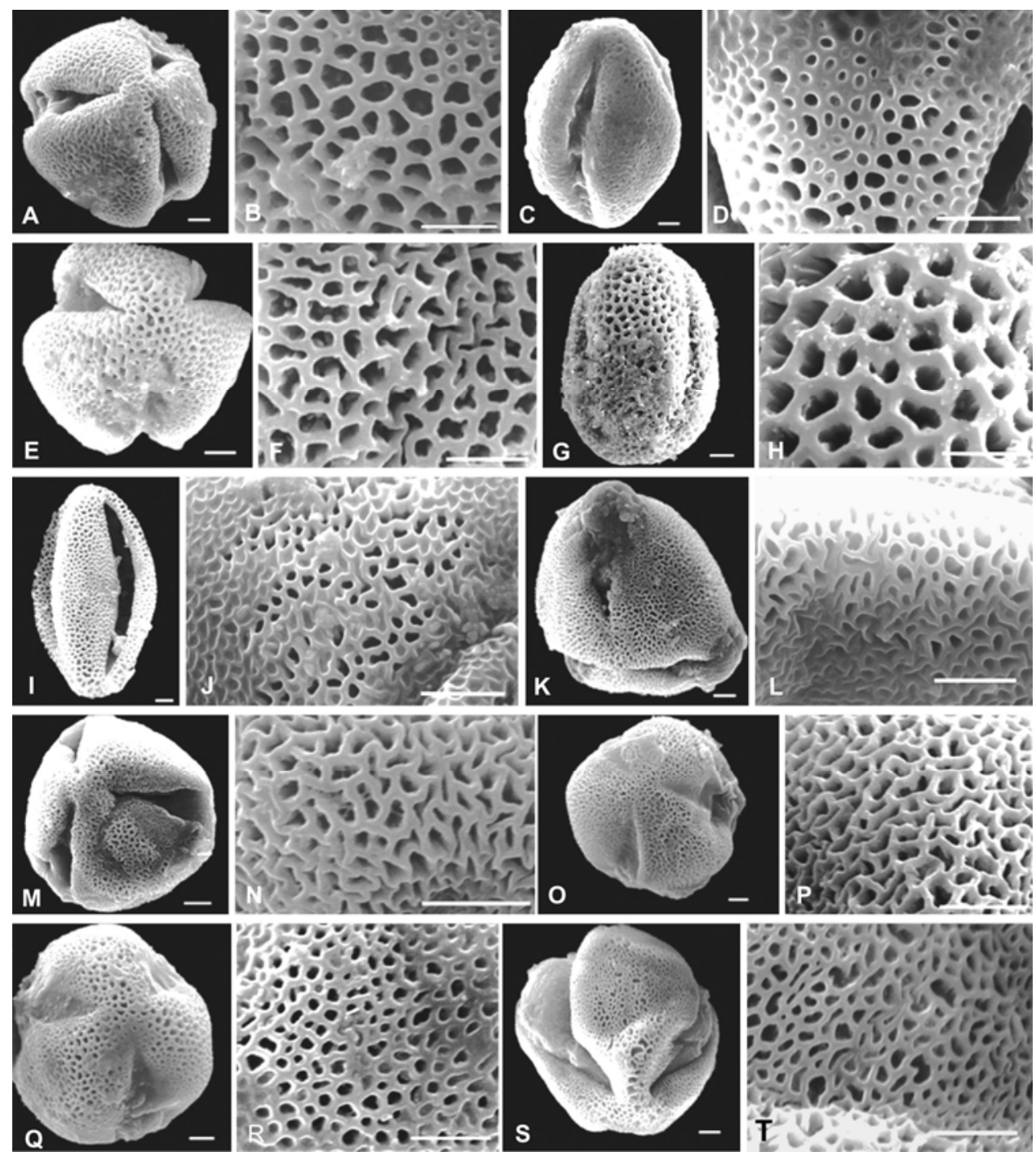

Fig. 2. SEM micrographs of the pollen grains of Verbascum. A, B. V. laetum; C, D. V. macrocarpum; E, F. V. oreophilum; G, H. V. palmyrense; I, J. V. pseudodigitalis; K, L. V. sinaiticum; M, N. V. sinuatum; O, P. V. songaricum; Q, R. V. speciosum; S, T. V. Thapsus; A, E, K, M, O, Q and S. polar view; B, D, F, H, $\mathrm{J}, \mathrm{L}, \mathrm{N}, \mathrm{P}, \mathrm{R}$ and T. exine sculpturing; C, G and I. equatorial view (Scale bar $=2 \mu \mathrm{m}$ ).

The overlapping of exine thickness is found among the taxa studied, thus this character is of little taxonomic value. Results obtained from the present study agree with previous studies on some species of Verbascum (Erdtman, 1952; Filippini et al., 1990; Lobin and Pormbski, 1994; 
Bokhri and Alfarhan, 2006; Asmat et al., 2011). Several authors reported two types of exine sculpturing for Verbascum i.e. microreticulate and macroreticulate (Kheiri et al., 2006; Pehlivan et al., 2008; Karavelioğullari et al., 2010). Pehlivan et al. (2008) concluded that the pollen morphological characteristics observed under the light microscope seems to have little value for taxonomic study but the sculpturing investigated under SEM provides a better result for dividing the Verbascum taxa into two groups with reticulate and coarsely reticulate. However, all taxa included in our study showed a uniform reticulate exine sculpturing pattern.

Our results showed that only the shape of pollen grains can be used for grouping the Verbascum into four groups viz. the Subprolate group including: $V$. alceoides, $V$. alepense, $V$. assurense, V. calvum, V. cheiranthifolium, V. geminiflorum, V. laetum, V. macrocarpum, V. songaricum, $V$. speciosum, the Prolate spheroidal group including: $V$. agrimoniifolium, $V$. carduchorum, V. oreophilum, V. palmyrense, and V. sinuatum; the Prolate group includes: $V$. andrusii, $V$. damascenum, $V$. pseudodigitalis, $V$. sinaiticum and the Oblate spheroidal with only one species $V$. thapsus. Even though the pollen characters alone cannot be used for species identification, they provide some information for the classification of these plants. Moreover, using this character in combination with other characters may help in clarifying some problematic taxa.

\section{Acknowledgement}

We gratefully acknowledge the staff of the Department of Biology, Faculty of Science, Khon Kaen University (KKU), Thailand, for their technical support and laboratory assistance. This study was supported by grants from the Scholarships \& Cultural Affairs Directorate, Ministry of Higher Education Scientific Research, Iraq.

\section{References}

AL-Bermani, A.K. 1981. Systematic study of the genus Verbascum (Scrophulariaceae) as it occurs in Iraq. M.Sc. Thesis in Biology/ Botany, University of Baghdad, Baghdad, Iraq.

AL-Rawi, A. 1964. Wild plants of Iraq with their distribution. Tech. Bull. 14. Dir. Gen. of Agr. Res. Proj. Iraq, Ministry of Agriculture, Government Press, pp. 1-323.

Asmat, T., Khan, M., Ahmed, M., Zafar, M., Manzoor, F., Munir, M., Akhtar, K., Bashir, S., Mukhtar, T., Ambreen, M. and Abbasi, S. 2011. Pollen morphology of selected species of Scrophulariaceae of district Dir Upper, Pakistan J. Med. Plants Res. 5: 6423-6428.

Bukhari, N.A. and Alfarhan, A.H. 2006. A study of some characteristics of pollen types of the genus Verbascum in Saudi Arabia. Saudi J. Biol. Sci. 13: 81-86.

Erdtman, G. 1952. Pollen Morphology and Plant Taxonomy: Angiosperms. Chronica Botanica Co., Massachusettes, USA, pp. 1-553.

Erdtman, G. 1960. The acetolysis method, a revised description. Svensk. Bot. Tidskr. 54: 561-564.

Filippini, R., Cappelletti, E.M. and Caniato, R. 1990. Botanical identification of powdered plant drugs Verbascum flowers. Int. J. Crude Drug Res. 28: 129-133.

Ghadanfar, S.A. 1992. An Annotated Catalogue of the Vascular Plants of Oman and their Vernacular Names. National Botanic Garden of Belgium, Meise, Belgium, pp. 1-153.

Huber-Morath, A. 1978. Verbascum L. In: Davis, P.H. (Ed.), Flora of Turkey and the East-Aegean Islands. Vol. 6. Edinburgh University Press, Edinburgh, UK, pp. 461-603.

Karavelioğullari, F.A., Celik, S., Başer, B. and Yavru, A. 2010. Verbascum ergin-hamzaoglui (Scrophulariaceae), a new species from South Anatolia, Turkey. Turk. J. Bot. 35: 275-283.

Kheiri, S., Khayami, M., Osaloo, S.K, and Mahmoodzadeh, A. 2006. Pollen morphology of some species of Verbascum (Scrophulariaceae) in Urmia. Pak. J. Biol. Sci. 9: 434-436. 
Lobin, W. and Pormbski, S. 1994. The genus Verbascum (Scrophulariaceae) on the Cape Verde Islands, W. Africa. Willdenowia 24: 65-81.

Özler, H., Pehlivan, S., Celep, F., Doğan, M., Kahraman, A., Yavru, A., Başer, B. and Bagherpour, S. 2013. Pollen morphology of Hymenosphace and Aethiopis sections of the genus Salvia (Lamiaceae) in Turkey. Turk. J. Bot. 37: 1070-1084.

Pehlivan, S., Başer, B. and Karavelioğullari, F.A. 2008. Pollen morphology of the genus Verbascum L. (Group A) in Turkey. Biodicon. 1: 1-24.

Perveen, A. 1993. A preliminary study of the pollen flora of Karachi. Ph.D. Thesis. Department of Botany. University of Karachi, Karachi, Pakistan.

Punt, W., Blackmore, S., Nilsson, S. and Le Thomas, A. 1994. Glossary of Pollen and Spore Terminology. LPP Foundation, Utrecht, Netherland, pp. 1-246.

Rajbhandary, S., Hughes, M. and Shrestha, K.K. 2012. Pollen morphology of Begonia L. (Begoniaceae) in Nepal. Bangladesh J. Plant Taxon. 19: 191-200.

Sarwar, A.K.M.G. and Takahashi, H. 2013. Pollen morphology of Rhododendron L. and related genera and its taxonomic significance. Bangladesh J. Plant Taxon. 20: 185-199.

Walker, J.W. and Doyle, J.A. 1975. The bases of angiosperm phylogeny: palynology. Ann. Mo. Bot. Gard. 62: 664-723.

Wood, J.R. 1997. A Handbook of the Yemen Flora. Royal Botanic Gardens, Kew, London, UK, pp. 1-434.

Zohary, M. 1974. Flora of Palestine. The Israel Academy of Sciences and Humanities. Jerusalem, Israel, pp. $1-519$.

(Manuscript received on 3 July 2014; revised on 3 December 2014) 